\title{
RECONCILING DUALITY AND DIVERSITYI DUALITÉ ET DIVERSITÉ SONT-ELLES CONCILIABLES?
}

\author{
Claude Ryan
}

\section{RECONCILING DUALITY AND DIVERSITY*}

I wish to thank the University of Alberta for the honorary degree which it has generously conferred upon me today. I accept with joy this high distinction because I assume that beyond my modest person you have wished, Madam Chancellor, to express your attachment to the linguistic duality of our country and to the unique role which history has devolved upon Québec in this respect. I also accept it with humility for I am well aware that the only degrees which count in life are those which accrue to deserving students following prolonged years of arduous study.

To you, members of this autumn's graduating class, I extend my sincere congratulations upon your success. To those who assisted you in the course of your long journey, in particular your parents, I address a word of admiration. By helping you as they did, they rendered an invaluable service not only to a son, a daughter, a brother, a sister, or a friend, but also to society in general.

I greatly admire those of you who, instead of seeking immediate gains, will devote additional years to the disinterested pursuit of knowledge. I presume however that a majority will now embark upon a practical career. Since I made the same choice some fifty years ago, at a time when a graduating student's options were much more

An address delivered at the University of Alberta on the occasion of the fall Convocation held at the Jubilee Auditorium, in Edmonton, on November 18, 1998. Published with the permission of Mr. Paul Ryan and the Ryan Family. Version française à suivre. limited, do not be surprised if my remarks, though they are meant for all of you, may seem to bear the imprint of my own experience.

Once you enter the business and professional world, your first obligation will of course be to excel in your own field of endeavor. Your degree will certify that you successfully mastered the essentials of your discipline. But it can only be a starting point. Since knowledge is continually renewed with ever-increasing rapidity, you will have to keep abreast of every development in your discipline and related fields. In order to excel, you must act conscientiously and competently in all matters, large and small, relating to your professional responsibilities. You must, in particular, serve the public with dignity, honesty, respect, courtesy and diligence. You must remain disposed at all times to change your methods of work whenever better ones become available. Regardless of what you think about them, you must also be prepared to abide by established rules as long as they have not been changed by regular procedures.

Thanks to your knowledge and skills, you will enjoy a higher measure of material comfort and better control over the organization of your life than the majority of your fellow citizens. But it would be a tragic waste if your talents were to be employed exclusively in the selfish promotion of your individual aggrandizement or pleasure. The more you learn about the workings of society, the more you will realize that insecurity, poverty and injustice are widespread among your fellowcitizens. You will also discover that society depends on your personal commitment to causes that transcend your immediate interests. From those 
who have received more, more must logically be expected in the service of the common good.

The society in which one is called upon to live cannot be an abstract and impersonal universe. It must be established on a given territory. It must have its own history. It must comprise members who, while different in several ways, are linked together by common values to which they all adhere. It must, in other words, be a nation. Among the values which help define a nation, language, culture, moral standards, religion, social customs, laws, and political institutions are most important. In spite of all that we hear nowadays and about the homogenizing impact of globalization and the alleged decline of nations, the latter will continue for a long time to provide the basic framework fo the organization of life in society. It would be superficial to think that the era of nations is over. The real questions in this area relate not to the survival of nations as such but to the nature and extent of the powers which of national governments will exercise and to the frontiers within which each nation will seek its destiny.

If this is true, Canada should normally continue to provide the social and political environment within which your lives will evolve and we would have many reasons to rejoice over that prospect. Our country forms, on this northern half of the American continent, a political society which is distinct, prosperous and free. Being neither too big nor too small, Canada is rich enough to provide citizens with a vast array of opportunities but not enough powerful to be suspected of imperialistic ambitions. Being able to listen with attention to smaller countries and to speak to the more powerful ones without fear of being ignored or silenced, it has enough weight to aspire to play a constructive role in international affairs. Having been founded on respect for diversity, it is well placed to serve as friendly interpreter or peace-keeper in conflicts arising elsewhere. We should be proud of the unique place which Canada occupies in the family of nations. But we must also be aware that our existence as a nation is perhaps more fragile today than at any other time since Confederation.

The most immediate threat to the unity of Canada arises from the ever-present possibility of an eventual breakup of the country. The first area of concern is of course the threat of separation emanating from Québec. Less spectacular but perhaps no less dangerous in the long term, are two trends which are now observable in Canada, i.e. on the one hand, a tendency on the part of prosperous regions to question the sharing of wealth and opportunity which has become synonymous with our federal system of government, and on the other hand, a tendency, particularly in Western Canada, to disregard our political tradition in favour of egalitarian concepts borrowed from the American political culture. The American experience was built upon the more or less absolute supremacy of individual rights. Canada opted on the contrary for a somewhat imperfect blending of individual and collective rights. A leading feature of the Canadian experience has been an attempt to accommodate the coexistence of two leading languages in a political society whose composition has kept changing over the years. The principles upon which this coexistence was founded are now openly challenged not only by those who want to build a sovereign state in Québec, but also by those who would abandon the bilingual and bicultural character of Canada in favour of an Americaninspired philosophy based exclusively on individual rights. If this latter approach were to prevail, I am afraid it would, over time, logically beget a very different Canada heralding the merits of multiculturalism but characterized in fact, almost everywhere, by English unilingualism, and from which Québec would likely have separated.

In the Trudeau years, equality between the French and the English languages was perceived as the best way to achieve national unity. We have accomplished significant progress in this direction. The most eloquent step towards linguistic equality was the enshrinement in the Constitution of a Canadian Charter of Rights and Freedoms in which certain linguistic rights are now explicitly guaranteed. But we have also learned from experience that linguistic equality can be fully achieved only in limited geographical areas or spheres of activity. From the standpoint of languages, the task of the future will consist:

1) in agreeing on some precise areas where there ought to be full equality between the two languages, for example in federal institutions, in the 
courts and in access to primary and secondary education;

2) in guaranteeing some limited but well-defined rights to the linguistic minority in those areas where one language must for all practical purposes be predominant;

3) in encouraging more and more Canadians, in addition to mastering their own language, to acquire a working knowledge of the other official language.

The presence on the campus of the University of Alberta of the Faculté Saint-Jean, which provides a variety of undergraduate programs in French, and the right which francophone parents of Alberta now enjoy, thanks to the present government of the province, to send their children to publicly-financed French schools over whose management they have control, are two fine examples of what I have in mind. They take nothing away from the predominant place of English in this province but remind us that French is an essential dimension of our Canadian character. Under the Canadian Charter of Rights and Freedoms, access to primary and secondary instruction in French must be provided in all provinces wherever it is warranted by a sufficient number to children. But access to a college education in the official minority language is not required by the Charter and is thus truly expressive, where it exists, of the Canadian spirit at its best. The existence in Québec of an elaborate network of English-speaking public schools, community colleges and universities provide another example of what I have in mind. In Québec, educational services for the official language minority are available at all levels of education. Those services are provided by institutions which are run everywhere by anglophones and benefit from public funding on a basis of strict equality with the French speaking network.

To anyone who has followed the debates of the past fifty years on national unity, it should be obvious that in addition to language rights, a better definition of the place and role of the province of Québec and of Western provinces in the Canadian federation will be needed if Canada is to reach durable unity.

The question of Québec was left in abeyance in the Constitution of 1867 and deplorably ignored in the Constitution of 1982. It has nonetheless emerged as a most fundamental and pressing issue. Québec is deeply different from other Canadian provinces on account of the language of the majority of its population, its Civil Code, its culture and institutions. For that reason, it has always refused and will continue to refuse being considered merely a province like the others. Its distinct character has been and remains a vital component of our Canadian identity. Québec wants to see its character more expressly recognized in our Constitution and more clearly accepted in the functioning of the federation. Whilst not asking for special privileges, it wants a recognition that will have real meaning and practical effects. Like many members of my generation, I gave up an interesting career in the private field in order to contribute as a full-time politician to the renewal of Canadian federalism along lines which must be acceptable to Québec and the rest of Canada. The closest we came to a solution was the Meech Lake Accord of 1987 which had to be abandoned three years later in the face of an opposition largely inspired from American egalitarian concepts and perhaps prompted by an exaggerated fear of words. We have found nothing better since the failure of the Meech Lake Accord in 1990 than the Calgary Declaration of 1997. The Calgary Declaration contains interesting overtures. But it remains too vague to be more than a modest starting point for discussion. In the absence of specific solutions, the attraction of sovereignty remains and will remain strong in Québec. Looking at these matters from a Western perspective, you might be tempted to conclude that they are not worth pursuing any further. But think of what we would all lose if Canada were to cease existing in its present form. A Canada with Québec will be better equipped to live side by side with the United States without running the risk of being gradually assimilated into the American culture. A Canada without Québec would be much weaker in this respect, not to speak of the centrifugal forces which would most probably undermine from within what would remain of its unity. A Québec separated from Canada would also, it seems to me, be in a much 
weaker position to deal the United States and the international community.

As regards the Western provinces, nothing better illustrates the new horizons which they open for Canada than the composition of this autumn's graduating class at the University of Alberta. The names of the hundreds of students who received their degree today are an eloquent illustration of the highly diverse origins of the population of Western Canada. This diversity is a tremendous asset for our country. It should be encouraged to express itself in ways that will add to the richness of our common heritage. The Western provinces, with their growing populations and wealth, justly wish to have a greater say in national institutions and decision-making processes. It is incumbent upon all of us to seek solutions which will respond to the legitimate aspirations of Western Canadians while not losing sight of the principles upon which Canada was and must remain founded.

I firmly believe that our best interest lies in accepting, rather than trying in vain to deny or minimize, our differences. We must try to accommodate them within a political society whose watch words ought to be recognition, mutual acceptance, interdependence and unity. My generation worked hard in order to attain that goal. But it succeeded only partially. It will be your responsibility to continue the work which we have begun and to bring it to completion. May God give you courage, understanding, imagination, generosity, patience and perseverance in the pursuit of that most noble ideal. May your endeavors also be crowned with success.

\section{DUALITÉ ET DIVERSITÉ SONT-ELLES CONCILIABLES?*}

Je veux remercier l'Université d'Alberta pour le doctorat honorifique qu'elle m'a généreusement décerné aujourd'hui. J'accepte avec joie cette distinction élevée parce que j'y vois, par-delà ma modeste personne, l'expression de votre attachement, madame la Chancelière, à la dualité linguistique de notre pays et au rôle-clé que

Allocution prononcée a l'Université d'Alberta à l'occasion de la cérémonie automnale de collation des grades tenue à l'auditorium Jubilee à Edmonton, le 18 novembre 1998. Publié avec la permission de maître Paul Ryan et de la famille Ryan. l'histoire a dévolu à cet égard au Québec. Je l'accepte aussi avec humilité car je sais pertinemment que les seuls diplômes qui aient une valeur dans la vie réelle sont ceux qui sont décernés à des étudiants méritants au terme de longues années d'études ardues.

À vous, membres de la promotion de cet automne, j'adresse mes sincères félicitations pour votre réussite. J'adresse aussi un mot d'admiration aux personnes qui vous ont assistés dans votre long cheminement. En vous aidant comme elles l'ont fait, ces personnes ont rendu un service signalé non seulement à un fils, à une fille, à un frère, à une sœur ou à un ami, mais aussi à toute la société.

J'ai beaucoup d'admiration pour ceux et celles d'entre vous qui, renonçant à chercher des gains immédiats, envisagent de consacrer de nouvelles années de leur vie à la recherche gratuite du savoir. Je présume cependant que la majorité d'entre vous vous engagerez maintenant dans le monde des affaires ou des professions. Comme je fis moimême un choix identique il y a quelque cinquante ans, à une époque où l'univers des options possibles au sortir des études universitaires était beaucoup plus limité qu'aujourd'hui, ne soyez pas étonnés si mes réflexions, même si je les destine à tous, vous donnent l'impression de porter surtout la marque de ma propre expérience.

Une fois engagés dans les affaires ou la pratique d'une profession, votre premier devoir sera évidemment d'exceller dans le domaine que vous aurez choisi. Votre diplôme attestera que vous avez appris avec succès les éléments essentiels de votre discipline. Mais il ne saurait être qu'un point de départ. Les connaissances se renouvellent continuellement, à un rythme sans cesse plus accélérer. Vous devrez en conséquence vous tenir au courant de tous les développements dans votre discipline et dans les domaines connexes. Afin d'exceller dans votre domaine, vous devrez agir de façon compétence et consciencieuse dans toutes les matières, petites et grandes, qui auront des rapports avec vos responsabilités professionnelles. Vous devrez en particulier servir le public avec dignité, honnêteté, respect, courtoisie et diligence. Vous devrez être disposé à modifier en tout temps vos manières de faire chaque fois que de nouvelles méthodes seront disponibles. Quoi que vous en pensiez, vous devrez aussi être disposés à agir dans 
le respect des règles établies aussi longtemps qu'elles n'auront pas été modifiées pas des procédures régulières.

À l'aide de vos connaissances théoriques et pratiques, vous aurez accès à un niveau plus élevé de confort matériel et à une plus grande mesure d'autonomie dans l'organisation de votre vie que la majorité de vos concitoyens. Mais si vos talents devaient servir uniquement à vous procurer une mesure plus forte de plaisir ou de puissance, ce serait là un tragique gaspillage. Plus vous apprendrez à connaître la marche de la société, plus vous verrez que l'insécurité, la pauvreté et l'injustice sont très répandues parmi vos concitoyens. Vous constaterez aussi que l'amélioration de la société dépend non seulement des partis politiques, des gouvernements et des moyens de communication, mais aussi de votre engagement personnel au service de causes qui transcendent vos intérêts immédiats. De ceux et celles qui ont reçu davantage, on doit logiquement attendre davantage pour le service du bien commun.

La société dans laquelle chacun est appelé à vivre ne saurait être un univers abstrait et impersonnel. Elle doit avoir pour base un territoire précis. Elle doit avoir sa propre histoire. Elle doit être formée de membres qui, tout en étant différents à plusieurs égards, sont reliés entre eux par une même adhésion à des valeurs communes. Elle doit en d'autres termes être une nation. Parmi les valeurs qui aident à définir une nation, la langue, la culture, les normes éthiques, la religion, les coutumes, les lois et les institutions politiques occupent une place très importante. On entend dire toutes sortes de choses, de nos jours, au sujet de l'homogénéité croissante qu'engendre la mondialisation et du déclin présumé des nations. Mais nonobstant tous ces bruits, les nations continueront pendant longtemps d'être la structure première pour l'organisation de la vie en société. Il serait superficiel de croire que l'ère des nations est terminée. Les questions que l'on doit se poser à ce sujet portent non pas sur la survie des nations comme telles mais plutôt sur la nature et l'étendue des pouvoirs qu'exerceront les gouvernements nationaux et sur les frontières à l'intérieur desquelles chaque nation sera appelée à poursuivre son destin.
Si les perspectives que je viens d'évoquer sont justes, le Canada devrait normalement continuer à fournir le cadre social et politique à l'intérieur duquel vous serez appelés à vivre. Et nous devrions nous réjouir de cette perspective. Car notre pays forme sur cette moitié septentrionale du continent américain un pays distinct, prospère et libre. $\mathrm{Ni}$ trop grand ni trop petit, le Canada est suffisamment riche pour offrir à ses citoyens une vaste gamme de chances mais pas assez puissant pour qu' on puisse lui prêter des ambitions impérialistes. Capable à la fois d'écouter avec attention les pays plus faibles et de parler aux pays plus puissants sans craindre d'être ignoré ou réduit au silence, il a tout juste assez de poids pour être en mesure d'aspirer de bon droit à un rôle constructif dans les affaires internationales. Ayant été fondé sur le respect de la diversité, il est bien placé pour intervenir à titre d'interprète de bonne volonté ou de gardien de la paix dans les conflits qui surgissent ailleurs. Nous devrions être fiers de la place unique que, grâce à ces atouts, le Canada occupe dans la famille des nations. Nous devons par contre être également conscients que l'existence de notre pays est peutêtre plus fragile aujourd'hui qu'à toute autre époque depuis les débuts de la fédération canadienne.

Parmi les dangers qui menacent l'unité du Canada, le plus immédiat est sans doute celui d'une éventuelle rupture du pays. La première source d'inquiétude provient à cet égard de la menace de séparation émanant du Québec. Même s'ils se manitestent de façon moins spectaculaire, deux courants d'opinion que l'on observe ces années-ci pourraient à long terme s'avérer tout aussi dangereux pour l'unité du pays. Un premier courant se manifeste dans les régions plus riches : il tend à remettre en question le partage de la richesse et des chances entre régions riches et pauvres que l'on identifie désormais avec l'expérience fédérale canadienne. Principalement répandu dans l'Ouest canadien, un second courant invite à déconsidérer la tradition politique canadienne au profit de concepts égalitaires empruntés à la culture politique américaine. L'expérience américaine s'est édifiée sur le fondement de la suprématie des droits individuels. Le Canada opta au contraire pour un système mixte où étaient appelés à cohabiter de manière imparfaite droits individuels et droits collectifs. La recherche d'une coexistence réussie entre deux langues principales au sein d'une même 
société politique dont la composition n'a cessé de changer au cours des années a été jusqu'à maintenant un trait caractéristique de l'expérience canadienne. Les principes sur lesquels fut fondée cette coexistence sont maintenant ouvertement remis en cause non seulement par ceux qui veulent faire du Québec un état souverain mais aussi par ceux qui seraient prêts à troquer le caractère bilingue et biculturel du Canada pour une philosophie d'inspiration américaine, fondée exclusivement sur les droits individuels. Cette dernière conception, si elle devait l'emporter, finirait, je le crains fort, par engendrer à la longue un Canada très différent où l'on proclamerait bien haut les mérites du multiculturalisme mais où l'unilinguisme anglais prévaudrait en réalité presque partout, et donc le Québec aurait probablement cessé de faire partie.

Sous M. Trudeau, l'égalité des langues anglaise et française fut perçue comme le meilleur moyen de réaliser l'unité du pays. Des progrès majeurs ont été accomplis dans cette direction. L'enchâssement dans la Constitution canadienne d'une Charte des droits et libertés dans laquelle une place importante a été réservée à la protection de certains droits linguistiques en est l'illustration la plus éloquente. Mais l'expérience nous a aussi appris que l'égalité souhaitée ne peut se réaliser pleinement que dans un nombre limité de régions géographiques et de sphères d'activité. En matière de langues, la tâche des années à venir consistera :

1) à identifier certains domaines précis, tels les institutions fédérales, le système judiciaire et l'accès à l'enseignement primaire et secondaire, où la pleine égalité des deux langues devrait être un objectif commun à tous le pays;

2) à garantir à la minorité linguistique certains droits limités mais nettement définis dans les régions où, à toutes fins utiles, il faudra accepter que l'une ou l'autre des deux langues soit prédominante;

3) à encourager un nombre croissant de Canadiennes et de Canadiens à acquérir, outre la maîtrise de leur propre langue, l'aptitude à communiquer aussi dans l'autre langue officielle.

La présence au sein de l'Université d'Alberta de la Faculté Saint-Jean, laquelle offre en français divers programmes de premier et de second cycle, et le droit que les parents francophones de l'Alberta se sont vu reconnaître, grâce au gouvernement de M. Ralph Klein, d'inscrire leurs enfants dans des écoles de langue française ayant droit à un financement public, égal et placées sous l'autorité de commissaires francophones, illustrent de manière intéressante en quoi pourrait consister l'approche que je suggère. Ces deux exemples ne diminuent en rien la prépondérance de la langue anglaise en Alberta mais ils nous rappellent que le fait français est une dimension essentielle du caractère canadien. L'accès de l'enfant à l'enseignement primaire et secondaire dans la langue de ses parents répond à une exigence de la Charte canadienne des droits et libertés, laquelle requiert que cet enseignement soit disponible partout où un nombre suffisant d'élèves le justifie. Par contre, l'accès à une formation universitaire dans la langue de la minorité linguistique n'est pas obligatoire en vertu de la Charte : là où il existe, il témoigne de ce qu'il y a de meilleur dans l'esprit canadien. Un autre exemple de ce que j'ai en tête nous est fourni par l'existence au Québec d'un réseau complet d'écoles publiques, de collèges communautaires et d'établissements universitaires anglophones. Ce réseau offre à la minorité anglophone une gamme complète de programmes éducatifs, à tous les niveaux d'enseignement. Les établissements qui le composent sont dirigés par des représentants de la communauté anglophone et bénéficient d'un financement public au même titre que les établissements francophones.

Pour qui a suivit l'évolution du débat constitutionnel au cours du dernier demi-siècle, il est devenu évident qu'il ne suffira pas de mieux protéger les droits linguistiques pour asseoir l'unité du pays sur des bases durables. Il faudra aussi mieux définir la place et le rôle du Québec et des provinces de l'Ouest au sein de la fédération.

La question du Québec fut plus ou moins laissée en suspens dans la Constitution de 1867. Elle fut déplorablement ignorée dans celle de 1982. Elle a néanmoins revêtu avec les années une importance fondamentale, voire pressante. Le 
Québec est profondément différent des autres provinces en raison de la langue parlée par la majorité de sa population, de sa culture, de son code civil et de ses institutions. Pour cette raison, il a toujours refusé et continuera de refuser de n'être qu'une province comme les autres. Son caractère distinct ayant été depuis les débuts du pays une composante majeure de notre identité canadienne, le Québec veut que ce caractère soit plus explicitement reconnu dans la Constitution et plus clairement accepté dans le fonctionnement de la fédération. Il ne demande aucun privilège mais il veut une reconnaissance qui ait une signification réelle et des effets concrets.

Comme plusieurs membres de ma génération, j'abandonnais un jour une carrière intéressante dans le secteur privé et m'engageais à plein temps dans la politique active afin d'y contribuer au renouvellement de la fédération selon des modalités acceptables au Québec et au reste du Canada. Avec l'Accord du lac Meech en 1987, nous vînmes très près d'une solution. Mais trois ans plus tard, il fallut renoncer à cette entente à cause d'une opposition largement inspirée de concepts politiques empruntés à la culture politique américaine et peut-être aussi d'une peur exagérée des mots. Nous n'avons rien trouvé de meilleur, depuis l'échec de Meech en 1990, que la Déclaration de Calgary de 1997. Celle-ci contient certes des ouvertures intéressantes. Mais elle est trop vague pour être autre chose qu'un point de départ plutôt modeste en vue de discussions éventuelles. En l'absence de solutions précises, l'attrait de la souveraineté demeure et continuera d'être fort au Québec. En observant ces choses à partir de l'Ouest canadien, vous pourriez être tentés de conclure qu'il n'y a pas lieu de perdre davantage de temps à en discuter. Mais pensez à ce que nous perdrions tous si le Canada, tel que nous le connaissons, devait cesser d'exister. Un Canada avec le Québec sera mieux équipé pour vivre côte à côte avec les États-Unis sans courir le risque d'une assimilation graduelle au sein de la culture américaine. Un Canada sans le Québec sera beaucoup plus faible pour affronter ce défi. Il devra en outre composer, selon toute probabilité, avec des forces centrifuges qui mineront fort probablement de l'intérieur ce qu'il lui restera d'unité. Un Québec coupé du Canada sera aussi à mon avis beaucoup plus faible pour transiger avec les États-Unis et la communauté internationale.
En ce qui touche les provinces de l'Ouest, rien ne saurait mieux illustrer les horizons nouveaux qu'elles ouvrent pour notre pays que la composition même du groupe de diplômés qui viennent de recevoir à l'occasion de cette collation des grades la consécration de leurs longues années d'études. La liste des noms de ces diplômés témoigne de l'extrême diversité des pays et des cultures d'où sont venus les habitants de l'Ouest canadien. Cette diversité est un atout extraordinaire pour le Canada. Nous devons faire en sorte qu'elle puisse s'exprimer sous des formes qui contribueront à l'enrichissement de notre patrimoine commun. Fortes d'une population et d'une richesse qui ne cessent de croître, les provinces de l'Ouest aspirent à juste titre à un rôle plus grand au sein des institutions canadiennes et des centres de décisions dont les choix affectent l'ensemble du pays. Il nous incombe à tous de chercher des solutions qui, tout en ne perdant pas de vue les principes sur lesquels le Canada fut fondé et doit continuer de reposer, feront droit aux requêtes légitimes de nos concitoyennes et concitoyens de l'Ouest du pays.

Je crois fermement qu'il est dans notre meilleur intérêt d'accepter nos différences plutôt que de chercher en vain à les nier ou à les minimiser. Nous devons chercher à leur faire une juste place au sein d'une société politique dont les valeurs-clés devraient être la reconnaissance, l'acceptation mutuelle, l'interdépendance et l'unité. Ma génération a consacré beaucoup d'efforts à la poursuite de cet objectif. Mais elle n'a connu que des succès limités. Il appartiendra à votre génération de poursuivre l'œuvre commencée et de la mener à terme. Puisse Dieu vous donner le courage, la capacité de comprendre, l'imagination, la générosité, la patience, la persévérance dont vous aurez besoin dans la poursuite de cet idéal très noble. Puissent aussi vos efforts être couronnés de succès.

\section{Claude Ryan}

